\title{
18S Ribosomal RNA
}

National Cancer Institute

\section{Source}

National Cancer Institute. 185 Ribosomal RNA. NCI Thesaurus. Code C48172.

The second largest of the three RNA components of the mammalian ribosome. 